INTERMATIONAL JOURNAL
PHARMACEUTICAL SCIENCES
PEANDCIH

Received on 15 October, 2011; received in revised form 23 January, 2012; accepted 28 January, 2012

\title{
FORMULATION AND EVALUATION OF TRANSDERMAL PATCH OF PREGABALIN
}

Chakshu Bhatia*, Monika Sachdeva and Meenakshi Bajpai

Department of Pharmacy, Raj Kumar Goel Institute of Technology, Ghaziabad, Uttar Pradesh, India

\begin{abstract}
Keywords:
Pregabalin,

transdermal,

HPMC,

PVP,

PVA,

EC,

Eudragit,

Propylene glycol

\section{ABSTRACT}

The objective of present study is to determine the permeation of Pregabalin from transdermal patch into microcirculation of skin. Matrix type transdermal drug delivery system (TDDS) of Pregabalin was prepared by the solvent evaporation technique. Several batches were prepared by using combination of HPMC and PVP; PVA and PVP; Eudragit RL-100 and Eudragit RS-100; HPMC and EC in different ratios. Propylene glycol was used as plasticizer and DMSO was incorporated as a permeation enhancer. Formulated transdermal patches were charachterised for their physicochemical parameters like thickness, weight variation, flatness, tensile strength, folding endurance, moisture content, moisture uptake and drug content uniformity. Patches were evaluated for their in-vitro drug release profile and ex-vivo skin permeation studies. Patches were also subjected to stability studies and skin irritation studies to determine their compatibility with skin. Formulation $\mathrm{P}_{1}$ containing HPMC and PVP in the ratio of 3:1 and propylene glycol, $5 \% \mathrm{w} / \mathrm{v}$ and DMSO, $6 \% \mathrm{w} / \mathrm{v}$ was found to be the most optimum formulation. $\mathrm{P}_{1}$ was also found to exhibit maximum in -vitro \%drug release of about $81.70 \%$. Result of evaluation studies revealed that Pregabalin can be administered as a controlled drug delivery system to reduce frequency of drug administration. But this hypothesis requires further confirmation via in-vivo pharmacodynamic and pharmacokinetic studies in animal and human models.
\end{abstract}

Correspondence to Author:

Chakshu Bhatia

Department of Pharmacy, Raj Kumar Goel Institute of Technology, Ghaziabad, Uttar Pradesh, India
INTRODUCTION: Pregabalin (PGB) is an anticonvulsant and analgesic drug ${ }^{1}$, which is required to be administered three to four times per day for its therapeutic effect by oral route of drug delivery in the treatment of partial seizures. It also finds its use in peripheral diabetic neuropathy, fibromyalgia and posttherapeutic neuralgia.

So, the objective of present work is to develop a controlled release dosage form of Pregabalin other than oral route and injectables. Hence, a non-invasive system in the form of transdermal patch of Pregabalin was thought to be developed and evaluated with the aim of achieving controlled release of Pregabalin over a prolong time period so that frequency of drug administration will be minimised.

Transdermal drug delivery has certain advantages over other systems of drug administration which in turn leads to increase patient compliance. Its non-invasive nature, ease of application and removal, predetermined rate of drug permeation, increased bioavailability of drug and decreased hepatic metabolism; all these factors make this system most suitable for systemic delivery of drug over long time periods of $24 \mathrm{hrs}$. 
Therefore, market of transdermal patches has made tremendous growth in recent years ${ }^{2,3}$.

MATERIALS: Pregabalin was obtained as gift sample from Torrent Pharmaceuticals, Ahmedabad. Polymers such as HPMC, PVP, PVA, Eudragit RL-100, Eudragit RS100 and EC was provided by the institute and other chemicals such as propylene glycol and DMSO and methanol used in the study were of analytical grade.

\section{METHOD:}

Technology Employed: Transdermal patch of Pregabalin was prepared by solvent evaporation technology. In this technology, mixture of polymer and drug solution was spread as a film on a suitable support (glass, mercury, aluminium foil etc.) and solvent was allowed to evaporate by keeping the petri dish containing solution for appropriate time period generally at room temperature. After evaporation of solvent, dried residue is the required patch containing drug trapped in the matrix of polymer ${ }^{4,5}$. The patch thus obtained was then evaluated for various parameters like physicochemical parameters, drug content, drug release profile and for skin irritation studies.

TABLE 1: COMPOSITION AND CHARACTERIZATION OF PLACEBO PATCHES

\begin{tabular}{ccc}
\hline POLYMERS & RATIO & PHYSICAL APPEARANCE \\
\hline HPMC: EC & $1: 2$ & Non-uniform film \\
EC: HPMC & $2: 4$ & Non-uniform film \\
PVA: PVP & $1: 3$ & Tough and hard film \\
PVP: PVA & $1: 2$ & Tough and hard film \\
Eudragit RL100: EudragitRS100 & $3: 1$ & Brittle and non-flexible film \\
HPMC: PVP & $1: 3$ & Smooth, transparent, uniform and flexible film \\
PVP: HPMC & $1: 1$ & Smooth, transparent and flexible film \\
\hline
\end{tabular}

TABLE 2: COMPOSITION OF PLACEBO PATCH OF HPMC AND PVP IN DIFFERENT RATIOS

\begin{tabular}{|c|c|c|c|c|}
\hline FORMULATION CODE & HPMC:PVP RATIO & Conc $^{\text {n. }}$ OF DMSO & CONC $^{n}$. OF PROPYLENE GLYCOL & FLEXIBILITY OF PATCH \\
\hline$P_{1}$ & $3: 1$ & $6 \%$ & $5 \%$ & Very flexible \\
\hline $\mathrm{P}_{2}$ & $1: 3$ & $4 \%$ & $6 \%$ & Moderately flexible \\
\hline $\mathrm{P}_{3}$ & $3: 5$ & $2 \%$ & $3 \%$ & Least flexible \\
\hline $\mathrm{P}_{4}$ & $5: 3$ & $1 \%$ & $2 \%$ & Least flexible \\
\hline$P_{5}$ & $1: 1$ & $3 \%$ & $4 \%$ & Fairly flexible \\
\hline $\mathrm{P}_{6}$ & $1: 1$ & $6 \%$ & $5 \%$ & Moderately flexible \\
\hline $\mathrm{P}_{7}$ & $1: 1$ & $5 \%$ & $6 \%$ & Moderately flexible \\
\hline
\end{tabular}

Fabrication of Medicated Patch of HPMC and PVP: Appropriate amount of hydroxypropylmethylcellulose and polyvinylpyrrolidone were weighed as per the ratio. These polymers were then dissolved in solvent system containing water: methanol (3:1). Drug solution
Preparation of different Placebo Polymeric Films: Different placebo patches are prepared by employing hit and trial method on various combinations of different hydrophilic and hydrophobic polymers ${ }^{6,7}$. From these various placebo patches, the combination having desired properties to support a transdermal drug delivery system is selected for incorporation of drug. Different combinations of polymers are as follows:

1. HPMC and PVP

2. HPMC and EC

3. Eudragit RL-100 and Eudragit RS-100

4. PVA and PVP

Table 1 below shows the composition and characterization of placebo patches prepared by using different polymers in different ratios. From the table 1, it was concluded that most appropriate combination of polymer was that of HPMC and PVP. Different ratios of HPMC and PVP were tried in order to obtain most optimum placebo patch. Composition and flexibility of placebo patch of HPMC and PVP combined in different ratio is shown below in table 2 . 
maintained at temperature not more than $30^{\circ} \mathrm{C}$ for about $6 \mathrm{hrs}$. After $6 \mathrm{hrs}$ petri dish was taken out of tray dryer and patch was removed and observed for its physical appearance and for various other parameters.
Such patches were found to be uniform, smooth and flexible. Composition of medicated patches of HPMC and PVP is shown in table $\mathbf{3}$.

TABLE 3: COMPOSITION OF MEDICATED HPMC: PVP PATCHES

\begin{tabular}{|c|c|c|c|c|c|c|c|}
\hline \multirow{2}{*}{ Name of Ingredients } & \multicolumn{7}{|c|}{ FORMULATION CODE } \\
\hline & $\mathbf{P}_{1}$ & $\mathbf{P}_{\mathbf{2}}$ & $\mathbf{P}_{3}$ & $\mathbf{P}_{4}$ & $\mathbf{P}_{5}$ & $\mathbf{P}_{6}$ & $\mathbf{P}_{7}$ \\
\hline Drug (gm) & 0.075 & 0.075 & 0.075 & 0.075 & 0.075 & 0.075 & 0.075 \\
\hline PVP (gm) & 0.5 & 1.5 & 2.5 & 1.5 & 0.5 & 1.5 & 2.5 \\
\hline Propylene Glycol (\%) & $5 \%$ & $5 \%$ & $5 \%$ & $5 \%$ & $5 \%$ & $5 \%$ & $5 \%$ \\
\hline
\end{tabular}

\section{Evaluation of Drug Loaded Patches of HPMC and PVP}

\section{Physicochemical Evaluation:}

Physical Appearance: Formulated patches were evaluated for their physical appearance, uniformity, entrapment of any air bubble or precipitation of drug, which on a large part determines patient acceptability of the patch and also therapeutic efficacy ${ }^{8}$.

Thickness: Thickness of Transdermal patch was measured by using Mitutoyo Digimatic Micrometer. Thickness of rectangular patch $(2 \times 2 \mathrm{cms})$ was determined at three different points and average thickness was calculated. Same was performed for other patches also. Thickness of each individual patch should not deviate significantly from each other ${ }^{8}$.

Weight Variation: Weight variation was studied by individually weighing 10 randomly selected patches and average weight was calculated. The individual weight should not deviate significantly from the average weight ${ }^{8,9}$.

Folding Endurance: Evaluation of folding endurance involves determining the folding capacity of the patches. Folding endurance is determined by repeatedly folding the patch at the same place until it break ${ }^{10}$. The number of times the patch could be folded at the same place without breaking is folding endurance value.

Tensile Strength: Mechanical properties of the polymeric patches were conveniently determined by measuring their tensile strength ${ }^{11,}{ }^{12}$. The tensile strength of the patches was determined by using an assembly designed to measure the tensile strength of the patch. Assembly consist of a pan hanged by using a strong thread and the other end of the thread was attached with the centre of the patch. The whole assembly was held like a beam balance and weights were kept on the pan. Weights required to break the patch was noted. Tensile strength was then calculated using the following formula:

\section{Tensile Strength $=$ Break Force/ $a \cdot b(1+\Delta L / L)$}

Where; $a=$ width of the patch, $b=$ thickness of the patch, $L=$ length of the patch, $\Delta L=$ elongation of patch at break point, Break Force $=$ weight required to break the patch $(\mathrm{Kg})$.

Moisture Uptake: Patch was kept in a desiccator at room temperature for $24 \mathrm{hrs}$. The patch was then taken out and exposed to $84 \%$ relative humidity using saturated solution of Potassium chloride in a desiccator until a constant weight is achieved. The \% moisture uptake was calculated by using following formula.

$$
\text { Final weight - Initial weight }
$$

$\%$ Moisture uptake=

$$
\text { Initial weight }
$$

Moisture Content: The prepared patches were weighed individually and kept in a desiccator containing calcium chloride at room temperature for $24 \mathrm{hrs}$. The patches were weighed again after a specified interval until they show a constant weight. The percent moisture content was calculated using following formula. 
Initial weight- Final weight

$\%$ Moisture content= $x 100$

Final weight

Drug Content Uniformity: Amount of drug entrapped in a patch was determined by completely dissolving a patch of size $2 \times 2 \mathrm{~cm}^{2}$ in $100 \mathrm{ml}$ phosphate buffer solution ( $\mathrm{pH}$ 7.4). Complete dissolution was achieved by placing the solution containing patch on shaker for about $24 \mathrm{hrs}$. Solution was then filtered and drug content was estimated spectrophotometrically at $210 \mathrm{~nm}$ after suitable dilution.

In-Vitro Permeation Studies: Permeation studies are carried out in order to determine transition of drug from patch to skin microcirculation. In this study, synthetic membrane like cellulose nitrate was placed between the donor and receptor compartment of Franz diffusion cell ${ }^{12,13}$. Receptor compartment was filled with phosphate buffer of $\mathrm{pH}$ 7.4. Transdermal patch was placed upon the cellulose nitrate membrane facing towards the donor compartment. The other side of cellulose nitrate membrane was towards the receptor compartment having phosphate buffer.

The receiver compartment was maintained at room temperature and was continuously stirred with the help of magnetic stirrer. Samples were withdrawn at specific time interval and equal amount of phosphate buffer was replaced each time to maintain volume of receptor compartment at a constant level. Samples withdrawn were then analysed for their absorbance and concentration was then calculated. Table 4 below shows the in-vitro permeation profile of drug from each batch. Graph was then plotted between \% drug release and time interval which compares \% drug release from different batches.

TABLE 4: DETERMINATION OF PHYSICOCHEMICAL PARAMETERS AND IN-VITRO DRUG RELEASE OF EACH FORMULATION

\begin{tabular}{|c|c|c|c|c|c|c|c|}
\hline $\begin{array}{l}\text { Formulation code/ } \\
\text { Physical parameters }\end{array}$ & $P_{1}(3: 1)$ & $P_{2}(1: 3)$ & $P_{3}(3: 5)$ & $P_{4}(5: 3)$ & $P_{5}(1: 1)$ & $P_{6}(1: 1)$ & $P_{7}(1: 1)$ \\
\hline Appearance & $\begin{array}{l}\text { Smooth, } \\
\text { uniform and } \\
\text { flexible }\end{array}$ & $\begin{array}{l}\text { Smooth, } \\
\text { uniform and } \\
\text { tough }\end{array}$ & $\begin{array}{l}\text { Rough, non- } \\
\text { uniform and } \\
\text { tough }\end{array}$ & $\begin{array}{l}\text { Rough, non- } \\
\text { uniform and } \\
\text { tough }\end{array}$ & $\begin{array}{l}\text { Smooth, } \\
\text { uniform and } \\
\text { flexible }\end{array}$ & $\begin{array}{l}\text { Smooth, } \\
\text { uniform and } \\
\text { flexible }\end{array}$ & $\begin{array}{c}\text { Smooth, } \\
\text { uniform and } \\
\text { flexible }\end{array}$ \\
\hline Thickness (mm) & $0.2795 \pm 0.3$ & $0.288 \pm 0.28$ & $0.1765 \pm 0.3$ & $0.198 \pm 0.2$ & $0.278 \pm 0.2$ & $0.274 \pm 0.3$ & $0.288 \pm 0.3$ \\
\hline \%Flatness & 100 & 100 & 100 & 100 & 100 & 100 & 100 \\
\hline Weight Variation (gm) & $2.754 \pm 1.5$ & $2.761 \pm 1.7$ & $4.758 \pm 1.5$ & $4.754 \pm 2.0$ & $1.711 \pm 1.8$ & $3.751 \pm 2.0$ & $5.798 \pm 1.5$ \\
\hline Folding Endurance & $90 \pm 1$ & $91 \pm 1$ & $88 \pm 1$ & $87 \pm 2$ & $90 \pm 1$ & $90 \pm 1$ & $91 \pm 2$ \\
\hline Tensile Strength & $3.20 \pm 0.3$ & $3.11 \pm 0.3$ & $2.99 \pm 0.2$ & $3.12 \pm 0.2$ & $3.20 \pm 0.2$ & $2.99 \pm 0.3$ & $3.12 \pm 0.2$ \\
\hline \%Moisture Content & $10.67 \pm 0.01$ & $10.80 \pm 0.05$ & $11.99 \pm 0.10$ & $11.01 \pm 0.01$ & $13.98 \pm 0.03$ & $13.11 \pm 0.03$ & $15.56 \pm 0.05$ \\
\hline \%Moisture Uptake & $22.50 \pm 0.15$ & $22.80 \pm 0.17$ & $22.99 \pm 0.13$ & $22.89 \pm 0.09$ & $23.87 \pm 0.13$ & $23.93 \pm 0.09$ & $24.76 \pm 0.09$ \\
\hline \%Drug Content & $99.99 \pm 0.8$ & $99.95 \pm 0.8$ & $86.84 \pm 0.7$ & $88.80 \pm 0.8$ & $99.86 \pm 0.7$ & $99.85 \pm 0.7$ & $99.88 \pm 0.7$ \\
\hline In-vitro Drug Release (\%) & 81.70 & 76.22 & 74.32 & 66.52 & 67.11 & 78.46 & 72.02 \\
\hline
\end{tabular}

In-Vitro Skin Permeation Studies: In-vitro skin permeation studies were carried out using rat's skin. Rat was sacrificed and skin was removed from abdominal portion ${ }^{12}$. Appropriate size of sin was shaved using depilatory cream and this skin was then used as a barrier between donor and receptor compartment of Franz diffusion cell. Transdermal patch $\left(P_{1}\right)$ was placed upon it (facing towards stratum corneum of the skin). Receptor compartment was filled with Phosphate buffer ( $\mathrm{pH} 7.4$ ) and magnetic bead was placed inside the receptor compartment. Franz diffusion cell was placed upon magnetic stirrer and temperature was maintained at about $37 \pm 0.5^{\circ} \mathrm{C}$. Samples were withdrawn at different time interval and equal amount of phosphate buffer was then added to the receptor compartment in order to maintain volume of the receptor compartment constant. Samples thus withdrawn were analysed by means of U.V Spectrophotometer in order to estimate amount of drug present in the sample.

Formulation $\mathrm{P}_{1}$ was initially found to exhibit maximum in-vitro drug release profile (table 5) where drug was permeated through cellulose nitrate membrane; moreover formulation $\mathrm{P}_{1}$ was found to possess other parameters also at a significantly optimum level; that's why $\mathrm{P}_{1}$ formulation was selected for drug permeation study across rat's skin. Data obtained from drug permeation study across rat's skin for the formulation $P_{1}$ is shown below in table 6 . 
TABLE 5: IN-VITRO PERMEATION RATE PROFILE OF BATCH $\mathrm{P}_{1}$

\begin{tabular}{cccccccc}
\hline Time (min.) & Absorbance & $\begin{array}{c}\text { Conc } \\
(\mu \mathrm{g} / \mathbf{m l})\end{array}$ & $\begin{array}{c}\text { Drug Amount } \\
(\mathbf{m g} / \mathbf{5 m l})\end{array}$ & $\begin{array}{c}\text { Cumulative amount } \\
\text { of drug release }\end{array}$ & $\begin{array}{c}\text { Drug Amount } \\
(\mathbf{m g} / \mathbf{1 5 m l})\end{array}$ & $\begin{array}{c}\text { Total Drug } \\
\text { release }\end{array}$ & $\begin{array}{c}\text { \% Drug } \\
\text { Release }\end{array}$ \\
\hline 0 & 0.000 & 0.000 & 0.000 & 0.000 & 0.000 & 0.000 \\
60 & 0.02 & 15.7 & 0.0789 & 0.000 & 2.355 & 2.355 \\
120 & 0.04 & 32.3 & 0.1615 & 0.0789 & 4.845 & 4.9239 \\
180 & 0.08 & 62.2 & 0.311 & 0.2404 & 9.330 & 9.5704 \\
240 & 0.103 & 79.5 & 0.3975 & 0.5514 & 11.92 & 12.4714 \\
360 & 0.143 & 110.6 & 0.553 & 0.9489 & 16.59 & 17.5389 \\
480 & 0.293 & 225.4 & 1.127 & 1.5019 & 33.81 & 35.3119 \\
600 & 0.424 & 326.4 & 1.632 & 2.6289 & 48.96 & 51.5889 \\
720 & 0.455 & 350.0 & 1.75 & 4.3789 & 52.50 & 56.62 \\
1440 & 0.478 & 367.69 & 1.838 & 6.1289 & 55.15 & 67.08 \\
\hline
\end{tabular}

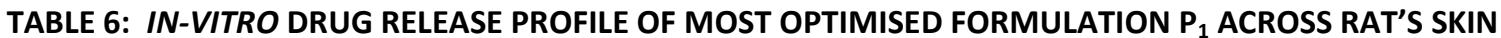

\begin{tabular}{|c|c|c|c|c|c|c|c|c|}
\hline $\begin{array}{l}\text { Time } \\
(\min )\end{array}$ & Abs. & $\begin{array}{l}\text { Dilution } \\
\text { factor }\end{array}$ & $\begin{array}{l}\text { Conc }^{n} \text {. } \\
(\mu \mathrm{g} / \mathrm{ml})\end{array}$ & $\begin{array}{l}\text { Drug Amount } \\
\text { (mg/5ml) }\end{array}$ & $\begin{array}{c}\text { Cumulative Drug } \\
\text { Release }\end{array}$ & $\begin{array}{l}\text { Drug Amount } \\
\text { (mg/15ml) }\end{array}$ & $\begin{array}{l}\text { Total Drug } \\
\text { Release }\end{array}$ & $\begin{array}{l}\text { \% Drug } \\
\text { Release }\end{array}$ \\
\hline 0 & 0 & 0 & 0 & 0 & 0 & 0 & 0 & 0 \\
\hline 120 & 0.037 & 1 & 29.0 & 0.145 & 0.006 & 4.35 & 4.356 & 5.80 \\
\hline 180 & 0.076 & 1 & 59.5 & 0.297 & 0.151 & 8.92 & 9.071 & 12.09 \\
\hline 240 & 0.104 & 1 & 80.1 & 0.400 & 0.448 & 12.01 & 12.458 & 16.61 \\
\hline 600 & 0.422 & 1 & 325.3 & 1.626 & 2.527 & 48.79 & 51.322 & 68.42 \\
\hline 720 & 0.455 & 1 & 350.3 & 1.7515 & 4.153 & 52.54 & 56.693 & 75.59 \\
\hline 1440 & 0.478 & 1 & 368.2 & 1.841 & 5.9045 & 55.23 & 61.134 & 81.51 \\
\hline
\end{tabular}

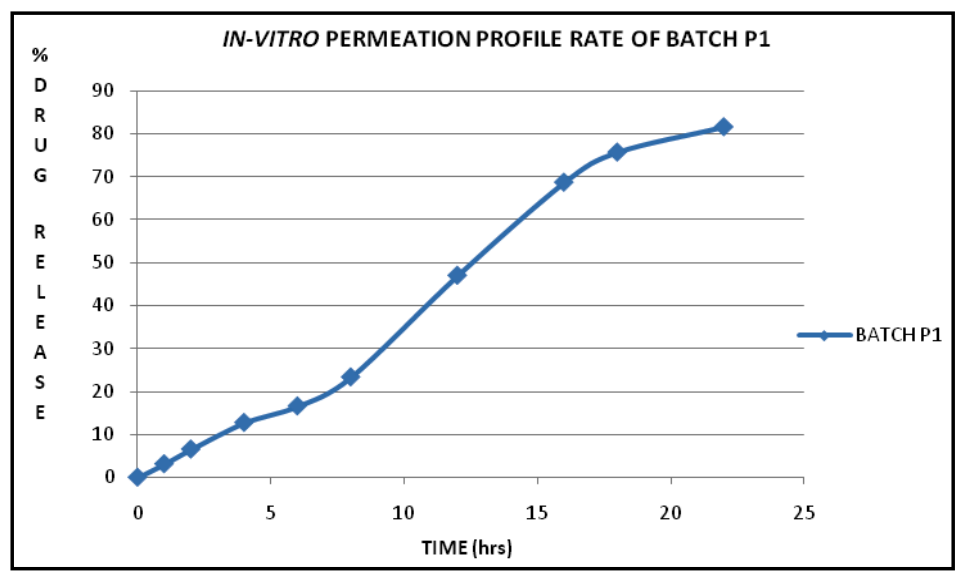

FIGURE 1: IN-VITRO PERMEATION RATE PROFILE OF BATCH P ${ }_{1}$

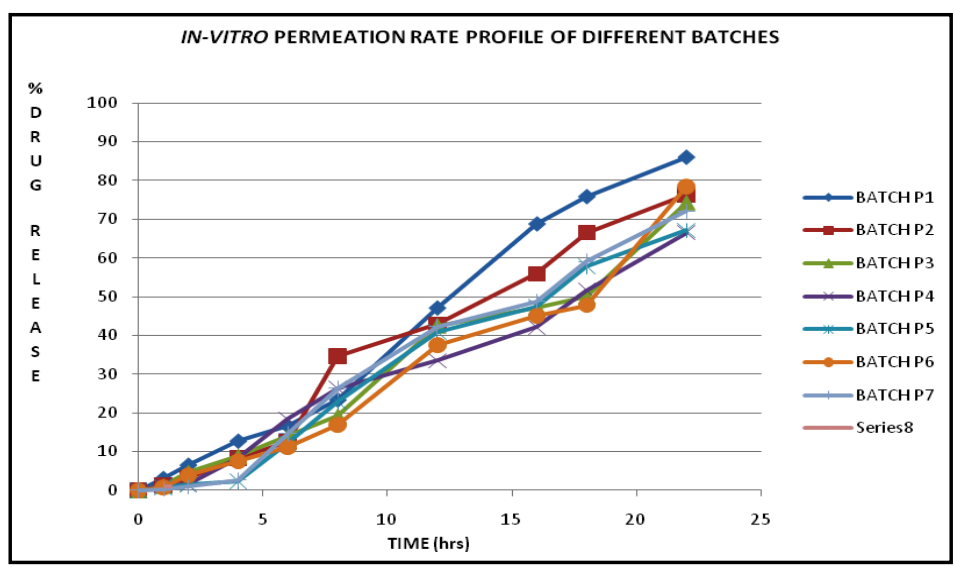

FIGURE 2: COMPARISON OF IN-VITRO PERMEATION RATE PROFILE OF DIFFERENT BATCHES OF TRANSDERMAL PATCH CONTAINING PREGABALIN

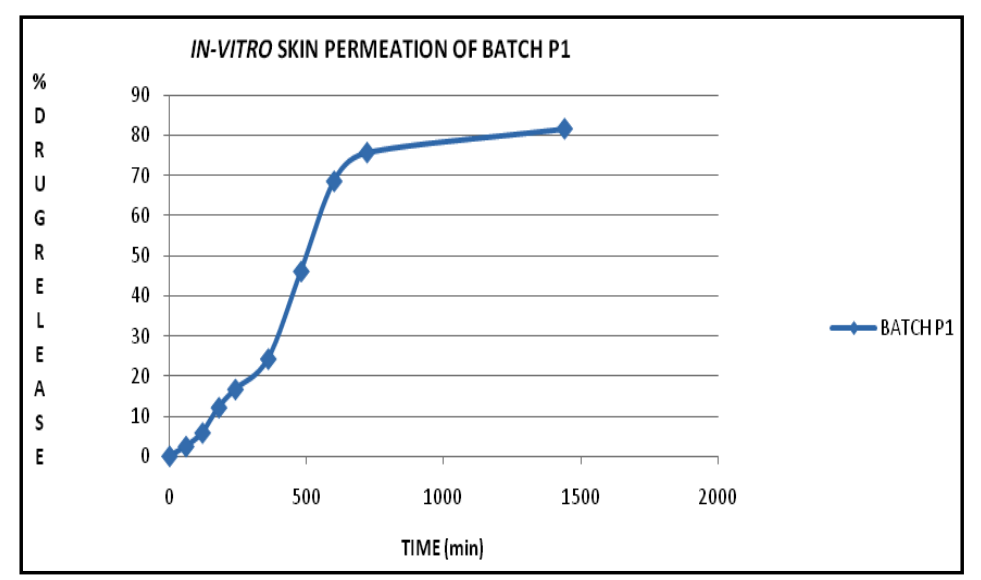

FIGURE 3: IN-VITRO DRUG RELEASE PROFILE OF BATCH $P_{1}$ ACROSS RAT'S SKIN

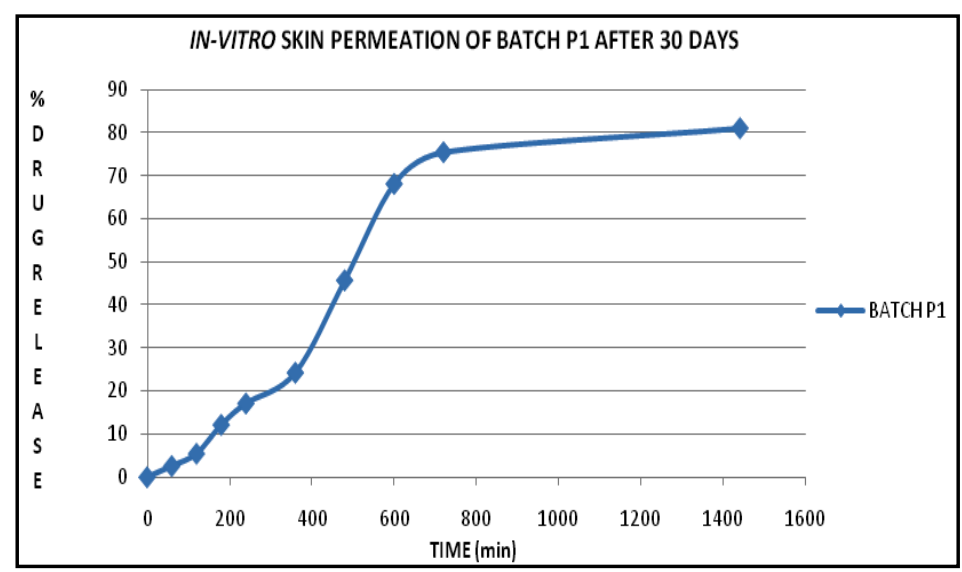

FIGURE 4: IN-VITRO DRUG RELEASE PROFILE OF BATCH $\mathrm{P}_{1}$ AFTER 30 DAYS 
Stability Studies: Stability of a TDDS is a very important factor to be considered while formulating such system because it affects therapeutic efficacy of the system as well as patient compliance. Here, formulated patches were wrapped in aluminium foil and kept at room temperature for a period of 30 days.

After completion of 30 days, patches were analysed for their drug release profile across rat's skin. Formulation $P_{1}$ was selected for this study as this formulation seemed quite promising throughout all evaluation studies performed previously on this formulation.
Formulation was also characterised for other parameters like physical appearance and physical parameters and drug content uniformity.

Procedure adopted for evaluation of formulation after 30 days was same as used earlier that is by using Franz diffusion cell containing phosphate buffer of $\mathrm{pH}$ 7.4. Samples withdrawn at different time intervals were analysed by U.V spectrophotometer to determine their concentration. Table 7 shows the drug release profile data after 30 days.

TABLE 7: IN-VITRO DRUG RELEASE PROFILE OF FORMULATION P 1 AFTER 30 DAYS

\begin{tabular}{|c|c|c|c|c|c|c|c|c|}
\hline $\begin{array}{l}\text { Time } \\
\text { (min) }\end{array}$ & Abs. & $\begin{array}{c}\text { Dil. } \\
\text { factor }\end{array}$ & $\begin{array}{l}\text { Conc }^{n} \text {. } \\
(\mu \mathrm{g} / \mathrm{ml})\end{array}$ & $\begin{array}{c}\text { Drug amount } \\
(\mathrm{mg} / 5 \mathrm{ml})\end{array}$ & $\begin{array}{c}\text { Cumulative drug } \\
\text { release }\end{array}$ & $\begin{array}{c}\text { Drug amount } \\
\text { (mg/15ml) }\end{array}$ & $\begin{array}{c}\text { Total drug } \\
\text { release }\end{array}$ & $\begin{array}{l}\% \text { drug } \\
\text { release }\end{array}$ \\
\hline 0 & 0 & 0 & 0 & 0 & 0 & 0 & 0 & 0 \\
\hline 60 & 0.0169 & 1 & 13.0 & 0.065 & 0 & 1.95 & 1.95 & 2.6 \\
\hline 180 & 0.0773 & 1 & 59.5 & 0.2975 & 0.2000 & 8.925 & 9.125 & 12.166 \\
\hline 240 & 0.1069 & 1 & 82.3 & 0.4115 & 0.4975 & 12.345 & 12.842 & 17.122 \\
\hline 600 & 0.4202 & 1 & 323.3 & 1.616 & 2.578 & 48.495 & 51.073 & 68.093 \\
\hline 720 & 0.4540 & 1 & 349.3 & 1.746 & 4.194 & 52.395 & 56.589 & 75.452 \\
\hline 1440 & 0.4751 & 1 & 365.5 & 1.827 & 5.940 & 54.825 & 60.765 & 81.02 \\
\hline
\end{tabular}

Skin Irritation Studies: Skin irritation studies were carried out in order to detect irritation and sensitization under conditions of maximal stress which may occur over a prolong contact with the skin surface. For this study rat was used as an animal model. Patch $\left(P_{1}\right)\left(2 \times 2 \mathrm{~cm}^{2}\right)$ was applied to the shaved skin of the rat on one side of the back and secured using adhesive tape. On other back side of the rat, control patch (without drug) was placed in a similar manner. Animal was then kept under observation for a period of $48 \mathrm{hrs}$ to detect any sign of erythma, redness, sensitization or any other allergic reaction.

RESULT AND DISCUSSION: Result of physicochemical parameters and in-vitro drug release profile is shown in Table 4. Result of in-vitro drug release across rat's skin is shown in Table 5. Stability studies indicate that drug release rate of transdermal patch does not reveal significant variation. It was found to be $81.02 \%$ for most optimised formulation $\mathrm{P}_{1}$, after keeping it for 30 days at room temperature and humidity. Skin irritation studies show no sign of erythma or any other skin irritation reaction, so it can be concluded that neither the drug nor any polymer or excipient was found to cause adverse effects on skin, hence, patch was found to be compatible with skin. Result of all evaluation parameters was found to be satisfactory within permissible limits.

CONCLUSION: From the present work it can be concluded that Pregabalin can be administered via matrix type transdermal drug delivery system, which provides controlled release which ultimately reduces the frequency of administration of drug in patients suffering from epilepsy and fibromyalgia. Hence this non-invasive, compatible patch with ease of application and removal may find increase patient compliance but present work required to be supported by further studies involving in-vivo pharmacodynamic and pharmacokinetic studies in animal and human models.

ACKNOWLEDGEMENT: The author is thankful to Department of Pharmacy, Raj Kumar Goel Institute of Technology, Ghaziabad (U.P.), India, for providing the facility to carry out the present research work under the guidance of Dr. Meenakshi Bajpai and Ms. Monika Sachdeva, who provided their kind help, efforts and support for the completion of this work. 


\section{REFERENCES:}

1. Indian Pharmacopoeia, Ministry of Health and Family Welfare, Government of India, 2010.

2. Remington, "The Science and Practice of Pharmacy", $21^{\text {st }}$ edition, Volume 1, published by B.I. Publications, 2006: 871876.

3. Chien Y.W, "Novel drug delivery system", $2^{\text {nd }}$ edition, vol-50, Marcel dekker, Inc, New York: 139-143.

4. Banker G.S., Rhodes C.T., "Modern pharmaceutics", Marcel dekker Inc., fourth edition, 2002: 667.

5. Naik A. et al, "Transdermal delivery-overcoming skin's barrier function", Pharmaceutical Science and Technology Today, drug Volume-3, Issue-9, September 2000: 318-326.

6. Kumar A.J., "Transdermal drug delivery system: an overview", International Journal of Pharmaceutical Sciences Review and Research, Volume-3, Issue 2, July 2010: 49-54.

7. Chandrashekhar N.S., "Physicochemical and pharmacokinetic parameters in drug selection and loading for transdermal drug delivery", Indian Journal of Pharmaceutical Sciences, Volume70, Issue 1, 2008: 94-96.
8. Damecha D.L., "Drug vehicle based approaches on penetration enhancement", International Journal of Pharmacy and Pharmaceutical Sciences, Volume-1, Issue 1, July 2009: 24-46.

9. Benson A.E.H, "Transdermal Drug Delivery: Penetration Enhancement Technique", Current Drug Delivery, Volume-2, 2005: 23-33.

10. Matteucci M., "A compact and disposable transdermal drug delivery system", Microelectronic Engineering, Volume-85, Issue 5-6, May -June 20008: 1066-1073.

11. Baert B., "A new discrimination criterion for the development of Franze diffusion test for transdermal pharmaceutics", J Pharm Pharmaceutic Sci, Volume 13(2), 2010: 218-230.

12. Guang M., Wang Li., "In-vitro and in-vivo characterization of clonidine transdermal patch treatment of attention deficit hyperactivity disorder in children", Biol Pharm. Bull Volume 28(2), 2004: 305-310.

13. Rowe C Raymond, Sheskey J Paul, and Weller J Paul, "Handbook of Pharmaceutical Excipients, published by Varghese publication, Mumbai, fourth edition, 2003: 219,297,521,508.

14. Hu Q. et al, "Enhanced transdermal delivery of tetracaine by electroporation", International Journal of Pharmaceutics, Volume-202, Issue 1-2, July 2000:121-124. 